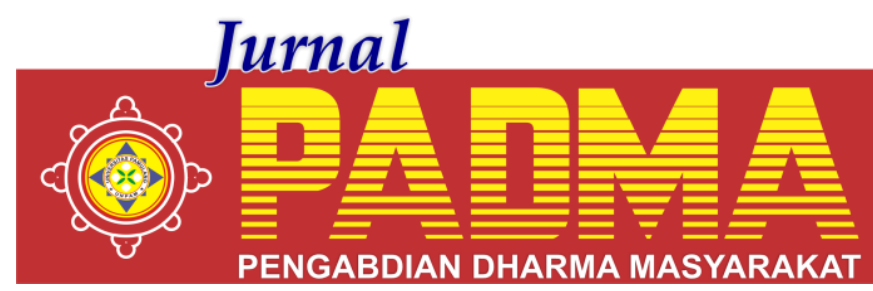

VOLUME I, NOMOR I, JANUARI 2021

\title{
PEMANFAATAN POTENSI LOKAL UNTUK PENINGKATAN EKONOMI KELUARGA WARGA BELAJAR PKBM BIMASDA KOTA TANGERANG SELATAN
}

\author{
${ }^{1 *}$ Indra Januar Rukmana, ${ }^{2}$ Catur Galuh Ratnagung, ${ }^{3}$ Dede Andi, ${ }^{4}$ Devi Fitria Wilandari, \\ 5Pancagaluh Ratnasih \\ Universitas Pamulang, Tangerang Selatan, Banten, Indonesia \\ *dosen02585@unpam.ac.id
}

\begin{abstract}
Abstrak
Permasalahan yang dihadapi oleh pelaku Warga belajar di PKBM Bimasda Kota Tangerang Selatan khususnya dalam pengembangan potensi SDM yang harus dibentuk sejak dini dikarenakan belum mengetahui potensi diri yang harus dikembangkan seperti apa dalam mendapatkan pelanggan serta belum dapat menentukan segmen pasar dan menyiapkan strategi yang tepat untuk bisa bersaing dengan kompetitor. Selain pengetahuan pengembangan diri yang sangat terbatas, cara manajemen untuk meningkatkan potensi yang ada saat ini masih kurang dalam hal tersebut. Kurangnya pengetahuan sampai dengan adaptasi terhadap internet dan perkembangan teknologi yang dialami pelaku warga belajar

PKBM Bimasda Kota Tangerang Selatan, menjadi tantangan dan masalah yang harus dicarikan solusinya. Bukan hanya itu, Permasalahan lain adalah minimnya pengetahuan warga belajar PKBM Bimasda tentang manajemen bisnis yang baik. Banyak warga belajar PKBM Bimasda hanya fokus memproduksi barang, tanpa memikirkan bagaimana strategi ekspansi bisnisnya lebih besar lagi. Akibatnya, warga belajar PKBM Bimasda kesulitan dalam meningkatkan level bisnisnya. Usaha yang mereka jalankan tidak berkembang dan omzet yang didapat tidak mengalami kenaikan.

Target luaran yang akan dicapai dalam kegiatan pengabdian masyarakat ini warga belajar PKBM Bimasda khususnya untuk membuka potensi diri dengan memiliki jiwa wirausaha (entrepreneur) yang mampu mengelolamanajemen usaha dan strategipemasaran yang baik.Artikelpengabdian yang dipublikasikan diJurnal terakredatis. Artikel termuat di media massa / Surat kabar nasional.
\end{abstract}

Kata Kunci : Manajemen, Pengembangan Diri

\section{Abstract}

Problems faced by the actors. Citizens learn at PKBM Bimasda Kota Tangerang Selatan, especially in the development of human resource potential that must be formed early on because they do not know what kind of potential to develop in getting customers and have not been able to determine the market segment and prepare the right strategy to be competitive with competitors. Apart from very limited self-development knowledge, management methods to increase the existing potential are still lacking in this regard. Lack of knowledge up to adaptation to the internet and technological developments experienced by learning citizens

The output target to be achieved in this community service activity is that the community members learn PKBM Bimasda especially to unlock their potential by having an entrepreneurial spirit (entrepreneur) who is able to manage good business management and marketing strategies. Service articles published in the most accredited journals. Articles published in the mass media / national newspapers.

Keywords: Management, Personal Development

\section{PENDAHULUAN}

PKBM Bimasda melibatkan banyak komponen masyarakat untuk menjadi penguat organisasi, sebagai pengajar dan juga sukarelawan. PKBM Bimasda bersama masyarakat ingin mewujudkan pendidikan nonformal gratis yang dapat merangkul masyarakat menengah ke bawah yang tid ak mendapat akses pendidikan formal atas berbagai alasan atau pun anak putus sekolah kar ena kesempitan ekonomi.

PKBM Bimasda digagas dalam rangka menyiapkan peserta didik berkualitas melalui pendi dikan Anak usia dini, pendidikan kesetaraan, pendidikan keaksaraan dan berkelanjutan yang dilaksanakan secara efektif dengan mengkedepankan kualitas pembelajaran yang sistematis dan terpadu. 


$\begin{array}{ccc}\text { Manfaat } & \text { Pengabdian } & \text { Keapda } \\ \begin{array}{c}\text { Masyarakat } \\ \text { Kegiatan }\end{array} & \text { Pengabdian } & \text { Kepada }\end{array}$
Masyarakat dari tim dosen dan masyarakat Universitas Pamulang hadir di PKBM Bimasda dalam bentuk pelatihan. Pelatihan ini akan melakukan pendekatan kekinian dengan metode diskusi berkelompok sehingga dapat lebih mudah dipahami oleh masyarakat PKBM Bimasda yang rata-rata adalah pemuda dan remaja milenial yang up to date dengan keadaan saat ini.

Beberapa materi pengelolaan keuangan, khususnya untuk masyarakat yang mendapatkan uang dari pekerjaan sampingan bisa menjadi langkah awal yang tepat untuk dilaksanakan oleh remaja menuju kemandirian ataupun kebebasan finansial atau financial freedom. Hal ini tentu akan bisa didapatkan pada saat sang anak ataupun remaja telah lulus kuliah dan mendapat pekerjaan, atau justru sudah memiliki kehendak bekerja sambilan (part time) saat masih sekolah pun kuliah.

Uang yang diterima sebagai upah bekerja itu apabila dikelola dengan baik sangat memberi arti, dapat menjadi peranan penting dalam pembentukan jati diri anak guna mempersiapkannya di masa mendatang. Sangat diharapkan dari pelatihan ini para masyarakat di PKBM BIMASDA dapat mengelola keuangannya degan cara yang sederhana, dan dapat membentuk karakter hemat dan bijak dalam mengelola keuangan.

\section{METODE}

Dalam pelatihan pemetaan potensi dasar peserta diminta untuk mengisi bagan SWOT. Peserta diminta mengidentifikasi kekuatan dan kelemahan dirinya. Peluang dan hambatan yang di hadapi dari hasil identifikasi tersebut narasumber membimbing warga belajar PKBM Bimasda untuk dapat mengetahui apa yang menjadi potensi dasar dirinya.

Dari identifikasi tersebut melalui teknik seminar, simulasi, pendekatan persuasif dan hypnoterapi peserta di berikan motivasi untuk meningkatkan kekuatan yang ada pada dirinya dan berusaha meminimalisir kekurangan yang ada pada dirinya. Juga dengan kekuatan tersebut diharapkan warga belajar PKBM Bimasda dapat menangkap peluang yang ada dengan baik.

\section{HASIL DAN PEMBAHASAN}

\begin{tabular}{lrr}
\multicolumn{1}{c}{ Kegiatan Pengabdian } & Kepada \\
Masyarakat ini berkaitan & erat \\
dengan memanajemenkan waktu & dan \\
pengembangan diri pada peserta.
\end{tabular}
Pemahaman akan pentingnya waktu haruslah disadari oleh usia remaja, dan PKBM Bimasda harus bisa membimbing setiap pelajar untuk dapat memahami keuangan dengan baik. Tingkat literasi keuangan yang rendah akan berdampak pada individu dan sosial. Berdasarkan hasil penelitian empiris, remaja yang memiliki tingkat literasi keuangan rendah akan mempunyai perilaku keuangan negatif ketika dewasa misalnya saldo tabungan minus, pembayaran kredit yang terlambat, tidak memiliki asuransi kesehatan dan tidak memiliki dana cadangan keuangan untuk keadaan darurat. Sedangkan, Individu yang mempunyai literasi keuangan tinggi akan lebih tangguh dalam menghadapi guncangan makroekonomi.

Ketidakmampuan masyarakat membuat keputusan finansial dapat menimbulkan dampak negatif pada seluruh aspek perekonomian suatu negara. Krisis keuangan dapat dipandang sebagai outcome dari kurangnya kompetensi keuangan dari warga negaranya. Sedangakn langkah-langkah menulis business plan yang baik adalah

Langkah 1: Mengenal Bisnis Anda. Pelajari dan pahami secara menyeluruh dan mendalam mengenai bentuk, potensi dan segala tantangan yang ada pada bisnis Anda. Dalam tahap ini Anda bisa menggunakan teknik analisa SWOT yang telah kita bahas sebelumnya. Anda bisa mempelajari hal-hal terkait bisnis ini dengan banyak cara seperti membaca buku dan referensi lain, bertanya dan berdiskusi pada ahli atau orang yang telah melakukannya sebelum Anda dan lainnya.

Langkah 2: Tentukan Visi Dalam Business Plan. Visi merupakan pandangan jauh tentang tujuan dan sasaran perusahaan memang harus dimiliki seluruh pebisnis skala besar hingga skala kecil. Dengan adanya visi yang jelas, maka Anda tak akan kesulitan nantinya dalam merancang alur dari rencana bisnis Anda. Nyatakan visi 
bisnis dan perusahaan Anda dengan bahasa dan kalimat yang jelas dan mudah dimengerti oleh orang lain.

Langkah 3: Tentukan Audiens Anda. Target audiens yang tepat, maka Anda bisa menyesuaikan konten business plan Anda dengan baik dan benar. Misalkan business plan untuk investor, maka Anda harus menyusun rencana bisnis tersebut dengan lebih serius, mendalam dan profesional.

Langkah 4: Tuliskan Rencana Bisnis Anda. Pernyataan Misi. Jelaskan satu hingga tiga paragraf singkat berisi misi dan tujuan bisnis Anda, tuliskan pula prinsip-prinsip yang dianut bisnis Anda serta menyatakan keunikan atau unique selling point (USP) yang membedakan antara perusahaan atau bisnis Anda dengan perusahaan lain yang bergerak di bidang yang sama.

Manajemen adalah usaha untuk melaksanakan suatu tujuan yang telah ditentukan dengan sistem yang dijalankan oleh semua orang didalam suatu kelompok/organisasi/perusahaan. Sehingga Manajemen mengandung fungsi sebagai

Perencanaan (Planning). Manusia harus memiliki perencanaan hidup yang baik sehingga kita harus merencanakan hendak dibawa kemana arah hidup kita.

Pengorganisasian (Organizing). Koordinasikan dengan baik apa yang telah sudah kita rencanakan dengan memperhatikan adanya berbagai pendapat diantara individu individu, seperti saudara, rekan, dan lingkungan luar dimana hal ini akan mempengaruhi keputusan dan tindakan yang diambil.

Pengarahan (Directing). Mengarahkan dengan benar arah hidup kita sehingga semua usaha yang kita lakukan dapat berjalan secara efektif dan efisien untuk mencapai tujuan yang kita harapkan.

Pelaksanaan (Implementing). Laksanakan/lakukan segala usaha terhadap apa yang sudah kita rencanakan dengan sungguh-sungguh, berikhtiar, dan berdoa. Berencana atas mimpi yang kita inginkantetapi tanpa ada usaha keras serta doa mustahil mimpi itu dapat terwujud.

\section{PENUTUP}

Hasil kegiatan PKM di PKBM Bimasda berjalan dengan lancar. Siswa terlihat antusias mempelajari materi dalam kegiatan manajemen dan pengembangan diri harus dimulai sejak dini karena jika anak-anak mendapatkan pendidikan manajemen dan pengembangan diri sejak dini, maka mereka kelak akan memperoleh pembelajaran kumulatif. Akan tetapi, saat ini informasi dan pendidikan manajemen dan pengembangan diri bagi remaja sangatlah terbatas, bahkan kurikulum pendidikan di Indonesia belum memasukkan pendidikan manajemen dan pengembangan diri. Di beberapa negara, pendidikan manajemen dan pengembangan diri sudah terintegrasi dalam kurikulum pendidikan dasar.

Tingkat literasi keuangan dipengaruhi oleh tingkat pendapatan dan pendidikan orang tua. Remaja dari keluarga ekonomi lemah mempunyai tingkat literasi keuangan lebih rendah dibanding remaja dari keluarga ekonomi tinggi. Remaja dengan orang tua yang berpendidikan rendah, memiliki tingkat literasi keuangan yang lebih rendah dibanding mereka dengan orang tua berpendidikan tinggi. Sehingga menyerahkan pendidikan keuangan ke keluarga bukan merupakan solusi, karena tingginya kesenjangan tingkat pendidikan dan tingkat penghasilan di Indonesia.

\section{DAFTAR PUSTAKA}

Alma. B. (2015), Manajemen Pemasaran dan Pemasaran Jasa, Bandung: Alfabeta Cummins. J. (2014), Sales Promotion, Jakarta: PPM

Barsah, A., Sudarso, A. P., \& Sunarsi, D. (2020). Analisis Pengaruh Pengajaran dan Sertifikasi Guru terhadap Kompetensi Guru pada Sekolah Menengah Kejuruan Di Wilayah Parung Panjang Kabupaten Bogor. Journal of Education, Humaniora and Social Sciences (JEHSS), 3(2), 650-657.

Beik, I. S., dan Arsyanti. L. D. (2016), Ekonomi Pembangunan Syariah, Jakarta: Rajawali Pers.

Erlangga, H. (2020). The Challenges of Organizational Communication in the Digital Era. Solid State Technology, 63(4), 1240-1246.

Kasmad, K., Mustakim, M., \& Sunarsi, D. (2020). Influences of Price, Promotion, and Service quality on Communities' Interest in Choosing Vocational High 
School. Journal of Educational Science and Technology (EST), 6(2), 233-243.

Kotler. P., \& Amstrong. G. (2016), Prinsipprinsip Pemasaran. Edisi 13. Jilid 1, Jakarta: Erlangga.

Kotler. P., \& Keller. K. L. (2016), PrinsipPrinsip Pemasaran. Edisi13. Jilid 1. Jakarta: Erlangga.

Manik, C. D., Sarwani, K., Triyadi, E. S. W., \& Sunarsi, D. (2020). The Effect of PDCA Cycle on Service Quality, Innovation Capability, and Work Performance of Indonesian Private Universities. PalArch's Journal of Archaeology of Egypt/Egyptology, 17(6), 8462-8483.

Mullins, J. W., \& Walker J. O. C. (2013). Marketing Management: A Strategic Decision-Making Approach, 8th Edition, McGraw-Hill International Edition.

Pratomo T. S, Soejoedono A. R. (2002). Ekonomi Skala Kecil/Menengah dan Koperasi. Jakarta: Ghalia Indonesia.

Rangkuti. F. (2014). Analisis SWOT: Teknik Membedah Kasus Bisnis. Jakarta. PT Gramedia Pustaka Utama.

Sampurnaningsih, S. R., Andriani, J., Zainudin, Z. A. B. A., \& Sunarsi, D. (2020). The Analysis of Entrepreneurship Character and Entrepreneurship Intention among Students. PalArch's Journal of Archaeology of Egypt/Egyptology, 17(6), 8290-8303.

Sobarna, A., Sunarsi, D., \& Roinadi, D. K. (2020). The Effect of Pedagogic Competence Kids Athletic toward Motivation for Elementary School. Solid State Technology, 63(6), 13641371.

Sobarna, A., Sunarsi, D., \& Roinadi, D. K. (2020). The Effect of Pedagogic Competence Kids Athletic toward Motivation for Elementary School. Solid State Technology, 63(6), 13641371.

Stanton, W. J. (2012). Prinsip Pemasaran, Alih Bahasa: Yohanes Lamarto. Jakarta: Penerbit Erlangga.
Sudaryono, (2016), Manajemen Pemasaran: Teori dan Implementasi, Yogyakarta: Penerbit Andi.

Sunarsi, D. (2019). Penerapan MSDM Strategis Dalam Upaya Meningkatkan Kemampuan Organisasi dalam menyongsong Revolusi 4.0. Jurnal Ilmiah MEA (Manajemen, Ekonomi, \& Akuntansi), 3(1), 221-233. https://doi.org/10.31955/mea.vol3.iss 1.pp221-233

Sunarsi, D. (2020). Kompetensi Dan Sertifikasi Guru Dalam Menunjang Kinerja Pada Pengajaran Berbasis Teknologi Informasi. Serang. Desanta Muliavisitama

Sunarsi, D. (2020). Menatap Wajah Pendidikan Indonesia Di Era 4.0: A Book Chapter of Indonesian Lecturer Associations. Serang. Desanta Muliavisitama

Swastha. B. (2012), Manajemen Penjualan, Edisi 3, Yogyakarta, BPFE.

Syobar, K., Hardiyan, A., Romlah, O. Y., Yusup, M., \& Sunarsi, D. (2020). The Effect of Service Quality and Price on Purchase Decisions in Woodpecker Coffee in South Jakarta. Solid State Technology, 63(6), 1491-1504.

Tambunan, Tulus. (2014). Perekonomian Indonesia (3 Ed.). Ghalia Indonesia. Winardi. (1989). Strategi pemasaran. Bandung: Mandarmaju.

Tjiptono. F. (2014), Pemasaran Jasa, Yogyakarta, Andi.

Yuangga, K. D., \& Sunarsi, D. (2020). Pengembangan media dan strategi pembelajaran untuk mengatasi permasalahan pembelajaran jarak jauh di pandemi covid-19. JGK (Jurnal Guru Kita), 4(3), 51-58. 